\title{
EFFICIENCY PERFORMANCE ANALYSIS OF PANIN DUBAI SYARIAH BANK IN COLLECTING AND DISTRIBUTING THIRD PARTY FUNDS BEFORE AND AFTER MERGER
}

\author{
Supriyono $^{1}$, Ahmad Rodoni ${ }^{2}$, Yacop Suparno ${ }^{3}$, Hermadi $^{4}$, Hilyatun Nafisah ${ }^{5}$ \\ 1,2,4 Universitas Islam Negeri Syarif Hidayatullah Jakarta \\ ${ }^{3,4}$ Universitas Sebelas Maret \\ E-mail: supri1101.sy@gmail.com,
}

\begin{abstract}
In this study, the researcher would make Panin Dubai Syariah Bank was the object of research on Islamic banks that carry out mergers and acquisitions. This research by using quarterly financial reports to determine the level of efficiency of the Panin Dubai Syariah Bank to be analyzed using the Data Envelopment Analysis (DEA) method. The researcher was used the annual report to find out the extent the Panin Dubai Syariah Bank carries out its Shariah values and objectives to be analyzed based on the Maqashid Index Sharia. In the non-parametric method, the approaches that can be used are Data Envelopment Analysis (DEA) and Free Disposal Hull (FDH). The results of the measurement of Bank Panin Dubai Syariah using DEA indicate that the decision to merge carried out by Panin Syariah Bank with Dubai Islamic Bank was the right decision because, with the merger, Panin Dubai Syariah Bank could produce almost perfect efficiency value of 99\% in the year 2015. With doing the merger, Bank Panin Dubai Syariah can minimize the inefficiencies that occur in the input variable so that it can maximize the efficiency that occurs in the output variable.
\end{abstract}

Key Word: Eficiency Performance, Collecting, Distributing, Merger

\section{INTRODUCTION}

The modern economy is characterized by the phenomenon of centralizing economic power and the transformation of industrial units from smaller to larger units as one of the effective ways to achieve economic progress. Mergers and acquisitions are the most significant ways of achieving centralized economic power.

The merger is a combination of two or more companies into one to strengthen the company's position. Whereas the acquisition is a takeover of part or all of the shares of another company so that the takeover company has control rights over the target company (Koesnadi, 1991). Acquisitions can be made to subsidiaries that have previously go public, and it called internal acquisitions or acquisitions of other companies, and it called external acquisitions.

The aim of the company to carry out mergers and acquisitions is expected to obtain synergies, namely the overall value of the company after mergers and acquisitions is greater than the sum of the value of each company before mergers and acquisitions. Mergers and acquisitions can also provide many benefits for companies such as increased marketing capabilities, research, managerial skills, technology transfer, and efficiency in the form of decreasing production costs (Hitt, 2002).

Mergers and acquisitions can be seen from two perspectives namely: first, the perspective of corporate finance, mergers and acquisitions is one form of long-term investment decisions (capital budgeting) that must be investigated and analyzed from the aspect of business feasibility. Second, the perspective of strategic management, mergers 
and acquisitions is an alternative strategy for the growth of the company through external channels to achieve company goals (Moin, 2003).

In mergers and acquisitions, two things should be considered, namely the value generated from the merger and acquisition and the parties who most benefit from the activity, with the hope, it will produce synergies so that the company's value will increase.

The activities of mergers and acquisitions in Indonesia have been going on since 1970, which were carried out by banks in the hope that they could strengthen the capital structure and obtain tax breaks. The development of the merger and acquisition continues until now. It was done by Panin Syariah Bank and Islamic Bank of Dubai in 2005 to improve the performance of Panin Syariah Bank.

Bank performance can not only be measured using financial statement performance and financial ratio performance or even with the CAMEL method but can also be measured by an efficiency approach. This efficiency analysis is based on the ability to produce maximum output with minimal input levels (Hadad et al., 2003). The concept of efficiency is related to the comparison between the number of inputs and outputs produced. Banks are more efficient that are expected to obtain optimal profits, obtain more loan funds and better quality services to customers.

In addition to the level of efficiency, the performance of Islamic banks also needs to be measured in terms of sharia by using the Maqashid Syariah Index. Maqashid Syariah Index is a model for measuring Islamic banking performance following the objectives and characteristics of Islamic banking. Based on public awareness that Islamic banks are developed as financial institutions that carry out business activities in line with the basic principles in Islamic economics by considering the role of Islamic banks as executors of social functions, namely to provide broad welfare to the society. Therefore the community as a sharia bank customer needs to know the extent of Islamic banks carry out sharia values and the extent of sharia objectives (maqashid sharia) are correctly implemented.

In this study, the researcher would make Panin Dubai Syariah Bank was the object of research on Islamic banks that carry out mergers and acquisitions. This research by using quarterly financial reports to determine the level of efficiency of the Panin Dubai Syariah Bank to be analyzed using the Data Envelopment Analysis (DEA) method. The researcher was used the annual report to find out the extent the Panin Dubai Syariah Bank carries out its Shariah values and objectives to be analyzed based on the Maqashid Index Sharia.

Indonesia is a country with the largest Muslim population in the world with a Muslim population of 88 per cent. The more advanced the system finance and banking, as well as increasing welfare and needs the community, especially Muslims so it causes a higher demand for banks following sharia principles (Alamsyah, 2015). This is proper for Indonesia can be a pioneer and direction for the development of Islamic finance in the world.

\section{LITERATURE REVIEW}

The business combination is one strategy to maintain survival and develop the company. The Indonesian accountant's association in the statement of Indonesian financial accounting standard Number 12 (PSAK No.22) defines the merger of a business entity as a form of uniting two or more separate companies into one economic entity because one company integrates with another company or obtains control over the assets and operations of another company (IAI, 2004). Types of business combinations can be divided into two, namely acquisition and pooling (Merger). 
The merger is one of the company's strategies in developing and growing a company. Mergers are derived from the merger (Latin) which means to join, together, combine to cause loss of identity due to this merger. A merger is defined as a merger of two or more companies which eventually joins one of the existing companies, thus eliminating one of the names of companies that merge. In other words, a merger is an agreement of two or more companies to join, then only one company remains alive as a legal entity, while the other stops activities or disburses (Moin, 2003).

While the acquisitions come from acquisitio (Latin) and acquisition (English), the acquisition means that buying or getting something/object to be added to something/object that has been owned previous. In business, chemistry acquisition can be interpreted as the takeover of ownership or control of shares or assets company by other companies, and in good corporate events, the takeover or who is taken over still exists as a legal entity separate (Moin, 2003).

In conducting mergers and acquisitions, managers must take into account the performance of the companies that will be acquired. Because of the performance of the company can assess whether or not the prospective company is acquired. The performance calculation is done by looking at financial ratios.

Bank performance can not only be measured using financial report performance, but an efficiency approach can also measure financial ratio performance or with the CAMEL method but. Efficiency analysis is based on the ability to produce maximum output with a minimum input level (Hadad et al., 2003). The concept of efficiency is related to the comparison between the number of inputs and outputs produced. Banks are more efficient that are expected to obtain optimal profits, obtain more loan funds and better quality services to customers.

Efficiency is the effort to achieve the highest possible achievement by using the possibilities available (material, machine and human) in the shortest possible time, in a real state (as long as the situation can change) without disturbing the balance between the objective factors, tools, energy and time (Wirapati, 1976). Efficiency can also be translated with usability, and in addition to the results, it is also emphasized on the efficiency of the effort/sacrifice to achieve these results in order to avoid waste (Syamsi, 2007).

Barr et al., (1999) argued that the efficiency of the company in production carried out one of two ways, namely maximizing output with predetermined inputs or minimizing inputs with predetermined outputs. The existing market reaction determines the company's choice of two things.

According to Abdul Wahab Khallaf, understanding about maqashid syariah can be used as a tool in understanding the editors of the Qur'an and Sunnah. In helping to resolve conflicting propositions (ta'arud al-adillab) and the most important thing is to establish the law in a case that determines the law is not listed in the Qur'an and Sunnah if it uses semantic studies (Anshori, 2009).

Al-Kuliyyat Al-Khams is a benefit of dharuriyah which is covered in five things which are considered as the basics and general objectives of the Shari'a that must be maintained: Maintaining Religion, Maintaining the Soul, Maintaining Intellect, Maintaining Descendants, and Maintaining Assets (Zahrah,1997).

The Maqashid syariah needed in the research of Mustafa, O.M and Dhuljastri Abdul Razak was based on the concept of maqashid syariah compiled by Muhammad Abu Zahrah in the book "UshulFiqh". Muhammad Abu Zahrah explained that the concept of maqashid syariah is broader and more general, namely the three objectives of Islamic law 
namely: Tahzib al-Fardi (Educating Humans), Iqamah Al Adl (Upholding Justice) and Jalb Maslabab (Public Interest) which are parameters based on these three aspects.

Tabel 1

Maqashid Syariah Index

\begin{tabular}{|c|c|c|c|c|}
\hline $\begin{array}{c}\text { Coocept } \\
\text { (Objectives) }\end{array}$ & Dimensioa & Element & Perfonmance Ratio & Sourced1 \\
\hline \multirow{4}{*}{$\begin{array}{l}\text { 1. Fducasing } \\
\text { todividial }\end{array}$} & \multirow{2}{*}{$\begin{array}{l}\text { Di.Advancement } \\
\text { Of Knowledge }\end{array}$} & $\begin{array}{l}\text { Fi. Idscation } \\
\text { grant }\end{array}$ & $\begin{array}{l}\text { RI. Education grant, } \\
\text { or scholarship/Tonal } \\
\text { Evpenses }\end{array}$ & $\begin{array}{l}\text { Aniwal } \\
\text { Repoet }\end{array}$ \\
\hline & & F2. Risutateft & $\begin{array}{l}\text { R2. Resuarti } \\
\text { EvpensirTisal } \\
\text { Eypenses }\end{array}$ & $\begin{array}{l}\text { Alimalal } \\
\text { Repest }\end{array}$ \\
\hline & $\begin{array}{l}\text { 102. Instiling eew } \\
\text { sblls and } \\
\text { improvement }\end{array}$ & F. Truinieg & $\begin{array}{l}\text { K. T. Trining } \\
\text { Expense/Total } \\
\text { Evoenses }\end{array}$ & $\begin{array}{l}\text { Anisial } \\
\text { Repoet }\end{array}$ \\
\hline & $\begin{array}{l}\text { D3. Creating } \\
\text { Awareness of } \\
\text { Islamic banking }\end{array}$ & E4 Publicity & $\begin{array}{l}\text { R4. Publicity } \\
\text { Expense/Total } \\
\text { expenses }\end{array}$ & $\begin{array}{l}\text { Anmuial } \\
\text { Repost }\end{array}$ \\
\hline \multirow{3}{*}{$\begin{array}{l}\text { 2. Entablishing } \\
\text { hustice }\end{array}$} & D4. Fair Retams & F5, Fair Redurms & 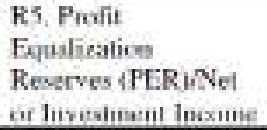 & $\begin{array}{l}\text { Aninal } \\
\text { Repoet }\end{array}$ \\
\hline & $\begin{array}{l}\text { D5.Cheap product } \\
\text { and } \\
\text { Servieve }\end{array}$ & $\begin{array}{l}\text { Eb Funcsional } \\
\text { Desirithation }\end{array}$ & 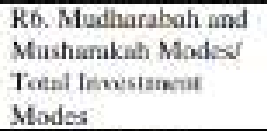 & $\begin{array}{l}\text { Annual } \\
\text { Kepeet }\end{array}$ \\
\hline & $\begin{array}{l}\text { D6. Dhimination of } \\
\text { negarive elements } \\
\text { thar beesd } \\
\text { Ejastices }\end{array}$ & $\begin{array}{l}\text { 17. Inberest free } \\
\text { Product }\end{array}$ & $\begin{array}{l}\text { R7. Inierest free } \\
\text { income /Total } \\
\text { Income }\end{array}$ & $\begin{array}{l}\text { Annwal } \\
\text { Repost }\end{array}$ \\
\hline \multirow{3}{*}{ 3. Public Interest } & D7. Frofitabelity & E\&. Frofil rabios & $\begin{array}{l}\text { R8. Nes Lcome/Total } \\
\text { ansets }\end{array}$ & $\begin{array}{l}\text { Anawal } \\
\text { Report }\end{array}$ \\
\hline & 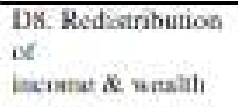 & $\begin{array}{l}\text { 19. Personal } \\
\text { inciome: }\end{array}$ & K9. Zakab/Net Asset & $\begin{array}{l}\text { Aninual } \\
\text { Kepeet }\end{array}$ \\
\hline & $\begin{array}{l}\text { D9. Investntent in } \\
\text { vitil real tector }\end{array}$ & $\begin{array}{l}\text { El Investment } \\
\text { nutios in mel } \\
\text { seclor }\end{array}$ & $\begin{array}{l}\text { RI lnvestment in } \\
\text { Real Fxonumxic } \\
\text { Sectod' Total } \\
\text { Investment. }\end{array}$ & $\begin{array}{l}\text { Ammoval } \\
\text { Reposi }\end{array}$ \\
\hline
\end{tabular}

Source: Adapted from Muhammad Syafii Antonio (2012)

\section{METHODOLOGY}

The frontier approach can be divided into parametric approaches and nonparametric approaches. The parametric approach takes measurements using stochastic econometrics and seeks to eliminate interference from the effects of inefficiency. While the non-parametric approach with linear programs ( non-parametric linear programming approach ) performs non-parametric measurements using an approach is not stochastic and tends to combine the interference into inefficiency. This is based on the discovery and observation of the population and evaluates efficiency relative to the units observed. In the non- parametric method, the approaches that can be used are Data Envelopment Analysis (DEA) and Free Disposal Hull (FDH).

DEA is a data-oriented approach in evaluating the performance of each entity unit called Decision Making Units (DMUs). The way it works is to change the multiple inputs output to the input which is a unit of measurement of efficiency or productivity. The efficiency score for each unit is relative, depending on the level of 
efficiency of the other units in the sample. Each unit in the sample is considered to have a level of efficiency that is not negative, and the value is between 0 and 1 , where 1 (one) shows perfect efficiency.

DEA is a fractional linear program model that can include many outputs and inputs without needing to specify weights for each previous variable, without the need for an explanation of the functional relationship between input and output.

\section{ANALYSIS OF DISCUSSION}

Tabel 2

The Level Efficiency of Panin Dubai Syariah Bank

\begin{tabular}{cccccc}
\hline & $\mathbf{2 0 1 3}$ & $\mathbf{2 0 1 4}$ & $\mathbf{2 0 1 5}$ & $\mathbf{2 0 1 6}$ & $\mathbf{2 0 1 7}$ \\
\hline Quarter I & $70 \%$ & $100 \%$ & $100 \%$ & $100 \%$ & $94 \%$ \\
\hline Quarter II & $100 \%$ & $100 \%$ & $100 \%$ & $100 \%$ & $91 \%$ \\
\hline Quarter III & $100 \%$ & $95 \%$ & $100 \%$ & $85 \%$ & $91 \%$ \\
\hline Quarter IV & $100 \%$ & $94 \%$ & $99 \%$ & $99 \%$ & $100 \%$ \\
\hline Average & $92 \%$ & $97 \%$ & $99 \%$ & $96 \%$ & $94 \%$ \\
\hline
\end{tabular}

Source: Secondary Data Processed

The results of measuring the efficiency level of Panin Dubai Syariah Bank from 2013 to 2017 (see Table 2) The periods of 2013 and 2014 were before the merger. While, the period 2015 to 2017 was after merger shows that the highest level of efficiency occurs when Panin Syariah Bank decides to merge with Dubai Islamic Bank, the value was 99\%, almost perfect efficiency. It shows that the decision of Panin Syariah Bank in conducting a merger was the right decision, as evidenced by the increased efficiency of Panin Dubai Syariah Bank which increased from the period before the merger was conducted. The lowest efficiency average occurred in 2013 with an efficiency value of $92 \%$. Even though it has not reached an absolute efficiency value of $100 \%$, the efficiency of Panin Dubai Syariah Bank during the study period was at almost perfect efficiency, which is above $90 \%$.

Tabel 3

Financial Performance of Panin Dubai Syariah Bank

\begin{tabular}{lccccccccccc}
\hline & & \multicolumn{3}{c}{ T } & \multicolumn{7}{c}{ Ac } \\
\cline { 2 - 12 } Total & $\mathbf{2 0 1 3}$ & $\mathbf{2 0 1 4}$ & $\mathbf{2 0 1 5}$ & $\mathbf{2 0 1 6}$ & $\mathbf{2 0 1 7}$ & $\mathbf{2 0 1 3}$ & $\mathbf{2 0 1 4}$ & $\mathbf{2 0 1 5}$ & $\mathbf{2 0 1 6}$ & $\mathbf{2 0 1 7}$ \\
\hline & TI & $40.3 \%$ & $0 \%$ & $0 \%$ & $0 \%$ & $5.2 \%$ & $59.7 \%$ & $100 \%$ & $100 \%$ & $100 \%$ & $94.8 \%$ \\
\cline { 2 - 12 } & TII & $0 \%$ & $0 \%$ & $0 \%$ & $0 \%$ & $8 \%$ & $100 \%$ & $100 \%$ & $100 \%$ & $100 \%$ & $92 \%$ \\
\cline { 2 - 12 } & TIII & $0 \%$ & $4.4 \%$ & $90 \%$ & $14.8 \%$ & $8.7 \%$ & $100 \%$ & $95.6 \%$ & $10 \%$ & $85.2 \%$ & $91.3 \%$ \\
\cline { 2 - 12 } & TIV & $0 \%$ & $5.2 \%$ & $0.1 \%$ & $0.2 \%$ & $0 \%$ & $100 \%$ & $94.8 \%$ & $99.9 \%$ & $99.8 \%$ & $100 \%$ \\
\hline Operational & TI & $29.4 \%$ & $0 \%$ & $0 \%$ & $0 \%$ & $5.2 \%$ & $70.6 \%$ & $100 \%$ & $100 \%$ & $100 \%$ & $94.8 \%$ \\
\hline
\end{tabular}




\begin{tabular}{|c|c|c|c|c|c|c|c|c|c|c|c|}
\hline \multirow[t]{3}{*}{ Costs } & TII & $0 \%$ & $0 \%$ & $0 \%$ & $0 \%$ & $8 \%$ & $100 \%$ & $100 \%$ & $100 \%$ & $100 \%$ & $92 \%$ \\
\hline & $\begin{array}{c}\text { TI } \\
\text { II }\end{array}$ & $39.6 \%$ & $\begin{array}{c}13 \\
7\end{array}$ & $0 \%$ & $74.3 \%$ & $8.7 \%$ & $60.4 \%$ & $86.3 \%$ & $100 \%$ & $25.7 \%$ & $91.3 \%$ \\
\hline & $\begin{array}{l}\text { TI } \\
\mathrm{V}\end{array}$ & $60.2 \%$ & $5.2 \%$ & $0.2 \%$ & $31.8 \%$ & $0 \%$ & $39.8 \%$ & $94.8 \%$ & $99.8 \%$ & $68.2 \%$ & $100 \%$ \\
\hline \multirow{4}{*}{$\begin{array}{c}\text { Non- } \\
\text { Operation } \\
\text { al Costs }\end{array}$} & TI & $30 \%$ & $0 \%$ & $0 \%$ & $0 \%$ & $64.3 \%$ & $70 \%$ & $100 \%$ & $100 \%$ & $100 \%$ & $35.7 \%$ \\
\hline & TII & $0 \%$ & $0 \%$ & $0 \%$ & $0 \%$ & $39.5 \%$ & $100 \%$ & $100 \%$ & $100 \%$ & $100 \%$ & $60.5 \%$ \\
\hline & TIII & $40.8 \%$ & $4.5 \%$ & $0 \%$ & $94.5 \%$ & $17.8 \%$ & $59.2 \%$ & $95.5 \%$ & $100 \%$ & $5.5 \%$ & $82.2 \%$ \\
\hline & TIV & $79.2 \%$ & $\begin{array}{c}92 . \\
2\end{array}$ & $\begin{array}{c}32.5 \\
\%\end{array}$ & $0.3 \%$ & $0 \%$ & $20.8 \%$ & $7.8 \%$ & $67.5 \%$ & $99.7 \%$ & $100 \%$ \\
\hline \multicolumn{2}{|c|}{ Average } & $26.6 \%$ & $\begin{array}{c}10 . \\
4\end{array}$ & $\begin{array}{c}10.2 \\
\% \\
\end{array}$ & $18 \%$ & $13.3 \%$ & $73,4 \%$ & $89.6 \%$ & $89.8 \%$ & $82 \%$ & $86.7 \%$ \\
\hline \multirow{4}{*}{ Collecting } & TI & $54.8 \%$ & $0 \%$ & $0 \%$ & $0 \%$ & $0 \%$ & $45.2 \%$ & $100 \%$ & $100 \%$ & $100 \%$ & $100 \%$ \\
\hline & TII & $0 \%$ & $0 \%$ & $0 \%$ & $0 \%$ & $1.2 \%$ & $100 \%$ & $100 \%$ & $100 \%$ & $100 \%$ & $98.8 \%$ \\
\hline & TIII & $0 \%$ & $0 \%$ & $0 \%$ & $0 \%$ & $3.4 \%$ & $100 \%$ & $100 \%$ & $100 \%$ & $100 \%$ & $96.6 \%$ \\
\hline & TIV & $0 \%$ & $0 \%$ & $1.3 \%$ & $0 \%$ & $0 \%$ & $100 \%$ & $100 \%$ & $98.7 \%$ & $100 \%$ & $100 \%$ \\
\hline \multirow[t]{4}{*}{ Financing } & TI & $0 \%$ & $0 \%$ & $0 \%$ & $0 \%$ & $0 \%$ & $100 \%$ & $100 \%$ & $100 \%$ & $100 \%$ & $100 \%$ \\
\hline & TII & $0 \%$ & $0 \%$ & $0 \%$ & $0 \%$ & $0 \%$ & $100 \%$ & $100 \%$ & $100 \%$ & $100 \%$ & $100 \%$ \\
\hline & T III & $0 \%$ & $0 \%$ & $0 \%$ & $4.9 \%$ & $0 \%$ & $100 \%$ & $100 \%$ & $100 \%$ & $95.1 \%$ & $100 \%$ \\
\hline & T IV & $0 \%$ & $0 \%$ & $0 \%$ & $0 \%$ & $0 \%$ & $100 \%$ & $100 \%$ & $100 \%$ & $100 \%$ & $100 \%$ \\
\hline \multicolumn{2}{|c|}{ Average } & $6.9 \%$ & $0 \%$ & $0.2 \%$ & $0.6 \%$ & $0.6 \%$ & $93.1 \%$ & $100 \%$ & $99.8 \%$ & $99.4 \%$ & $99.4 \%$ \\
\hline
\end{tabular}

Source: Secondary Data Processed

The bank's performance in collecting and channelling third-party funds (TPF) was measured using some indicators. Namely total assets, operational costs, non-operational costs, fundraising, and costing shows the average total assets, operational costs and nonoperational costs (see Table 3 Achieved). The input variable in 2013 was 73.4\%, in 2014 it was $89.6 \%$, in 2015 was $89.8 \%$, in 2016 was $82 \%$, and in 2017 was $86.7 \%$. It shows that the value of inefficiency was still high in input variables. Although the value of these inefficiencies tends to decrease compared to the conditions before the merger and after the merger conducted by Panin Dubai Syariah Bank. It means that the merger decision made by Panin Dubai Syariah Bank could improve bank performance and reduce the value of inefficiencies that occur in banks.

Whereas, the result data from the fundraising and financing indicators as output variables (see Table 3 Achieved) shows that the average fund collection and financing during the research period was achieved absolute efficiency values in 2014. In the periods of 2013,2015 to 2017 were achieved almost perfect values no less of $90 \%$. It shows that the value of the inefficiency in the input variable was decreased because the effects of the merger carried out by Panin Dubai Syariah Bank affected the efficiency of the output variable as an indicator of the performance of Islamic banks in channelling deposits.

The results of this research in which the input variables namely total assets, operational costs and non-operational costs are variables that cause inefficiencies in the performance of Islamic banks. This research in line with the research results of Yulita and Rizal (2016) where several factors lead to inefficiencies in Islamic banks namely operational 
costs, assets fixed, total financing, third-party funds.

Tabel 4

Performance Ratio of Maqashid Syariah Index in Panin Dubai Syariah Bank

\begin{tabular}{cccccc}
\hline & \multicolumn{6}{c}{ Performance Ratio of Educating } \\
\cline { 2 - 6 } & $\mathbf{2 0 1 3}$ & $\mathbf{2 0 1 4}$ & $\mathbf{2 0 1 5}$ & $\mathbf{2 0 1 6}$ & $\mathbf{2 0 1 7}$ \\
\hline Education Grant (\%) & 2009 & 1,922 & 0.405 & 0.482 & 0.158 \\
\hline Research (\%) & 2009 & 1,922 & 0.405 & 0.482 & 0.158 \\
\hline Training (\%) & 2009 & 1,922 & 0.405 & 0.482 & 0.158 \\
\hline Publicity (\%) & 0.792 & 3,199 & 2,485 & 2.041 & 3.135 \\
\hline
\end{tabular}

Source: Secondary Data Processed

The data in table 4 shows that the ratio of education grants, research and training to Panin The data in table 4 shows that the ratio of education grants, research and training to Panin Dubai Syariah Bank has the same value and fluctuated from 2013 to 2017. However, the value of the ratio in all three these variables tend to decline from 2015 to 2017. In the period, Panin Dubai Syariah Bank has carried out a merger process to improve bank performance. The highest ratio value was in 2013 amounting to 2,009 \%, and the lowest value ratio was in 2017 amounting to $0.158 \%$.

This result shows that Panin Dubai Syariah Bank has fluctuated channelled the same amount of funds each year for education through scholarships and educational infrastructure used as programs to improve the quality of education for underprivileged families, for research to increase innovation in bank products, and also for training with increasing bank employee performance.

The ratio of publicity of Panin Dubai Syariah Bank has the highest value ratio among the proper educating performance ratios during the study period. The ratio value also experienced significant fluctuations in each period. The highest value of the ratio was in 2014 amounting to 3,199\%, and the lowest value was in 2013 amounting to $0.792 \%$. The highest fluctuations occur when Panin Dubai Syariah Bank has before a merger and after the merger occurs the fluctuations that occur was not too significant and tended to be stable. The promotion strategy is carried out by Panin Dubai Syariah Bank through print and electronic media and BTL (Below The Line) programs such as sponsorship events, business gatherings, ATM receipts, brochures, exhibitions and event outlets in malls, offices, car-free days and so on.

Tabel 5

Performance Ratio of Maqashid Syariah Index in Panin Dubai Syariah Bank

\begin{tabular}{cccccc}
\hline & \multicolumn{4}{c}{ Establishing Justice Performance Ratio } \\
\cline { 2 - 6 } & $\mathbf{2 0 1 3}$ & $\mathbf{2 0 1 4}$ & $\mathbf{2 0 1 5}$ & $\mathbf{2 0 1 6}$ & $\mathbf{2 0 1 7}$ \\
\hline Fair Returns (\%) & 65,678 & 10.431 & 7.361 & 7.252 & 10.22 \\
\hline Functional Distribution (\%) & 103,861 & 296,807 & 369,164 & 241,808 & 224.20 \\
\hline Free Interest Product (\%) & 2.188 & 13,473 & 10.390 & 3,938 & 119,11 \\
\hline
\end{tabular}

Source: Secondary Data Processed 
In table 5 , the fair return ratio of Panin Dubai Syariah Bank has fluctuated during the period 2013 to 2017. This ratio has the highest value in 2013 of $65,678 \%$ the total revenue of Panin Dubai Syariah Bank. However, in next year the fair return ratio of Panin Dubai Syariah Bank has experienced a significant decline. In 2016 was the peak of the decline in the fair return ratio was amounted to $7.252 \%$. This result shows that the business of Panin Dubai Syariah Bank in increasing profits obtained in order to increase profit sharing to customers and banks through merger activities was considered less effective because the value of the ratio in the current year after the merger occurs tends to decrease compared to the year before the merger occurred.

The functional distribution ratio is reflected through the ratio of profit sharing scheme ( mudharabah and musyarakah ) to total financing. Panin Dubai Syariah Bank had the highest value ratio in 2015 was amounting of 369,164\%, but it was following by a decrease in each subsequent year. Even though, in 2015 there was an increase of 72,357 $\%$. This result shows that Panin Dubai Syariah Bank in every year strives to improve its function in realizing socio-economic justice by increased the financing of Islamic banks using the mudharabah and musyarakah models.

The interest-free income ratio is reflected through interest-free income compared to total The interest- free income ratio was reflected through interest-free income compared to total income. Panin Dubai Syariah Bank had the highest ratio value in 2017 was of 119,119 $\%$, the highest ratio was a very significant increase when compared to the previous year, the increase reached was115,181\%. This result shows that Panin Dubai Syariah Bank took the merger decision to obtain interest-free income by minimising interest income from the placement of funds and current accounts in conventional banks is the right decision.

Tabel 6

Performance Ratio of Maqashid Syariah Index in Panin Dubai Syariah Bank

\begin{tabular}{cccccc}
\hline & \multicolumn{5}{c}{ Public Interest Performance Ratio } \\
\cline { 2 - 6 } & $\mathbf{2 0 1 3}$ & $\mathbf{2 0 1 4}$ & $\mathbf{2 0 1 5}$ & $\mathbf{2 0 1 6}$ & $\mathbf{2 0 1 7}$ \\
\hline Profit Ratio (\%) & 0.278 & 1,142 & 1,035 & 0.311 & 10,952 \\
\hline Personal Income (\%) & 0 & 0.013 & 0.053 & 0.026 & 0.008 \\
\hline Investment In Real Sector (\%) & 9,773 & 89,889 & 375,266 & 76,065 & 248,789 \\
\hline
\end{tabular}

Source: Secondary Data Processed

From table 6, Panin Dubai Syariah Bank had the highest Profit Ratio in 2017 was of $10,952 \%$ which experienced a significant increase of $10,641 \%$ from the previous year. During the study period, the profit ratio of Panin Dubai Syariah' Bank has experienced a significant increase. This result shows that with the merger carried out by Panin Dubai Syariah' Bank succeeded to increase the net profit earned every year, and it will have an impact on improving the function of public interest not only the owners and employees of Islamic banks but also all stakeholders of Islamic banking.

The ratio of personal income was reflected through the level of public interest obtained by society through zakat paid by Islamic banks. Panin Dubai Syariah' Bank has the highest ratio value in 2015 with an increase of $0,04 \%$ from the previous year but has decreased by $0.027 \%$ in 2016. Panin Dubai Syariah Bank was routine pays at least $2.5 \%$ of the total profits to pay zakat. This result shows that Panin Bank Dubai Syariah every year consistently pays zakat by achieving goals for the benefit of society. 
The investment in the real sector ratio was reflected through the investment of Islamic banks in the real sector compared to the overall investment in Islamic banks. Panin Dubai Syariah Bank had the highest fixed value ratio in 2015 was of 375,266 \%. However, in the next year was decreased. Panin Dubai Syariah Bank was selected several products in the distribution of the real sector through musyarakah financing, murabahah, mudharabah, qard and other sharia products.

\section{CONCLUSION}

The merger is one of the company's strategies in developing and growing a company. While the acquisition means buying or getting something/object to be added to something/object that has been owned previous. In conducting mergers and acquisitions, managers must take into account the performance of the companies that will be acquired. Because of the performance of the company can assess whether or not the prospective company is acquired. The performance calculation was done by looking at financial ratios.

Bank performance can not only be measured using financial report performance, but an efficiency approach can also measure financial ratio performance or with the CAMEL method but. Efficiency analysis is based on the ability to produce maximum output with a minimum input level. In addition to the level of efficiency, the performance of Islamic banks also needs to be measured in terms of sharia by using the Maqashid Syariah Index, to measure the performance of Islamic banking to appropriate the objectives and characteristics of Islamic banking.

The results of the measurement of Bank Panin Dubai Syariah using DEA indicate that the decision to merge carried out by Panin Syariah Bank with Dubai Islamic Bank was the right decision because, with the merger, Panin Dubai Syariah Bank could produce almost perfect efficiency value of $99 \%$ in the year 2015. With doing the merger, Bank Panin Dubai Syariah can minimize the inefficiencies that occur in the input variable so that it can maximize the efficiency that occurs in the output variable.

Similarly, the results of sharia side measurements using Maqasid Syariah Index, the merger carried out by Dubai Sharia Bank can improve the side of sharia bank so that the bank could fulfill the objectives and characteristics of Islamic banks following Islamic law.

\section{REFERENCES}

Abdul-Rahman, Yahia. The Art of Islamic Banking and Finance : Tools and Techniques for Community- Based Banking. United States of America : Willey Finance. 2010.

Al-Hemyari, Ameen Baggash Abdulhemed. Merger and Acquisition Laws In UK, UAE and Qatar: Transferring Rights and Obligations. Thesis Brunei University School of Law. 2012

Anshori, Isa. "Maqāșid Al-Syari'ah Sebagai Landasan Etika Global". Jurnal Hukum Islam, Vol. 01, No.01, Maret. 2009

Antonio, Muhammad Syafi'I, Yulizar D. Sanrego dan Muhammad Taufiq. "An Analysis of Islamic Banking Performance: Maqasid Index Implementation in Indonesia and Jordania". Jurnal of Islamic Finance IIUM, Vol. 1 No. 1. 2012.

Auda, Jasser. Maqasid Al-Shariah As Philosophy Of Islamic Law : A System Approach. London: The International Institute Of Islamic Thought. 2007.

Awan, Abdul Ghafoor. Impact of Mergers and Acquisitions on the Performance of 
Commercial Banks in Pakistan. Journal of Poverty, Investment and Development Vol. 16. 2015.

Bank Indonesia. Syamsi, Ibnu. Efisiensi, Sistem dan Prosedur Kerja. Jakarta: PT. Bumi Aksara. 2007.

Barr, R. S, K. A. Killgo, T. F. Siems, S. Zimmel. Evaluating The Productive Efficiency and Performance of U.S. Commercial Banks, Federal Reserve Bank of Dallas. Research Department, Dallas. Texas. 1999.

Bauer, P. W., Berger A. N, G. D. Ferrier, dan D. V. Humphrey. Consistency Condition For Regulatory Analysis Of Financial Institutions: A Comparison Of Frontier Efficiency Methods, Financial Services Working Paper. 02/97. Federal Reserve. 1998

Berger, A. N. \& Humphrey, D. B. Efficiency Of Financial Institution: International Survey and Directions For Future Research. European Journal Of Operation Research, 98(5): 175-212. 1997.

Bhuia, M. R, Azizul, B., Kamil, A. A., \& Deb, N. Evaluation Of Online Bank Efficiency In Bangladesh: A Data Envelopment Analysis (DEA) Approach. Journal Of Internet Banking and Commerce, 17(2): 1-17. 2012.

Chui, Andy BS. WH lp. Improving Merger and Acquisition Decision-Making Using Fuzzy Logic and Simulation. International Journal Of Engineering Business Management Vol 9: 1-18. 2017

El Tiby, Amr Mohamed. Islamic Banking : How To Manage Risk and Improve Profitability. United States of America : Willey Finance. 2011

Hadad, M. D, W. Santoso, D. Ilyas dan E. Mardanugraha. Analisis Industri Perbankan Indonesia: Penggunaan Metode Non Parametrik Data Envelopment Analysis. Research Paper Bank Indonesia. 2003

Hadad, M. D, W. Santoso, D. Ilyas dan E. Mardanugraha. Pendekatan Parametrik Untuk Efisiensi Perbankan Indonesia. Research Paper Bank Indonesia. 2003

Hartono, Imam, S. Djohar, H. K. Daryanto. Analisis Efisiensi Bank Perkreditan Rakyat Di Wilayah JABODETABEK Dengan Pendekatan Data Envelopment Analysis. Journal of Management \& Agribusiness Vol.5 No.2 Oktober 2008

Hitt, M. A.. Merger dan akuisisi: Panduan bagi para pemegang saham untuk meraih laba, terjemahan. Cetakan Pertama. Jakarta: Erlangga. 2002

Ikatan Akuntan Indonesia. Standar akuntansi keuangan. Jakarta: Salemba Empat. 2009

Malik, Muhammad Faizan, et al. Mergers and Acquisitions: A Conceptual Review. International Journal of Acounting and Financial Reporting. Vol. 4 No. 22014

Nia, N. M., Alouj, H. A., Pireivatlou, A. S. \& Ghezelbash, A. A Comparative Profitability Efficiency Study Of Private And Government Banking System in Iran Applying Data Envelopment Analysis (DEA). Journal Of Basic and Applied Scientific Research. 2(11): 11603-11614. 2012

O.M, Mustafa dan Dzuljastri Abdul Razak. The Performance Measures of Islamic Banking Based On The Maqasid Framework. International Islamic University Malaysia: Department of Economics, Kulliyyah of Economics, and Management of Economics. 2008.

Payamta \& Setiawan. Analisis pengaruh merger dan akuisisi terhadap kinerja perusahaan publik di Indonesia. Jurnal Riset akuntansi Indonesia, 7(3). 2004.

Subekti, I. Investigasi Empiris Cost-Efficiency Perbankan Indonesia Berdasarkan Metode Data Envelopment Analysis (DEA). Lintasan Ekonomi, 21(1): 95-115. 
2004.

Suliyanto,. D. P. Jati. Perbandingan Efisiensi Bank Perkreditan Rakyat dan Bank Umum Dengan Pendekatan Data Envelopment Analysis. Jurnal Keuangan dan Perbankan Vol. 18 No. 2 Mei: 297-306. 2014.

Wilson, A. Manajemen Perbankan Indonesia: Teori dan Implementasi. Jakarta: LP3ES. 2006. 